SECTION 20. Medicine.

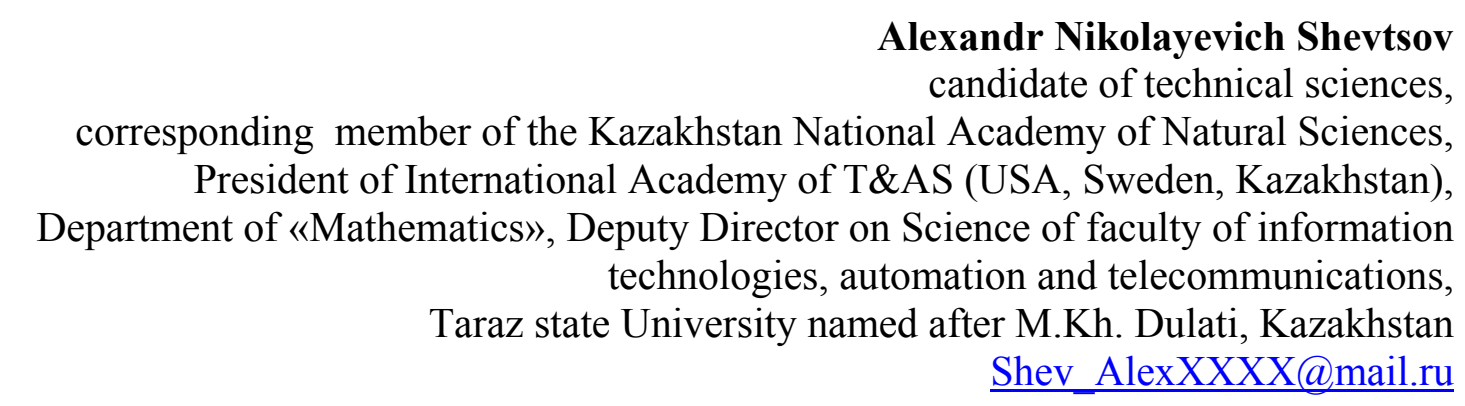

Ulmeken Mukhitovna Smailova

candidate of physical and mathematical Sciences, associate Professor, Branch of JSC National centre of improvement of qualification of «Orleu» Institute for professional development of Zhambyl region, Kazakhstan samilova tarsu@mail.ru

Victoriya Yuryevna Pautova metrologist

LLP Medicine Repair Standardization, Kazakhstan

\title{
THE ANALYSIS OF STATISTICS FOR THE CERTIFICATION OF MEDICAL ORGANIZATIONS OF KAZAKHSTAN FOR 2010
}

\section{Abstract: The article considers the statistics certificate on attestation, verification and inspection on medical equipment. \\ Key words: medical equipment, statistics certification, medical organizations, certification. \\ АНАЛИЗ СТАТИСТИКИ СЕРТИФИКАЦИИ МЕДИЦИНСКИХ ОРГАНИЗАЦИЙ КАЗАХСТАНА ЗА 2010 ГОД}

Аннотация: В статье рассматривается статистика по выдаче сертфикатов об аттестации, поверок и актов испытаний на медицинское оборудование.

Ключевые слова: медицинское оборудование, статистика сертификаиии, медицинские организациии, сертификация.

«Республиканское государственное предприятие на праве хозяйственного ведения «Казахстанский институт метрологии» (КазИнМетр) Комитета технического регулирования и метрологии Министерства индустрии и новых технологий Республики Казахстан» создано постановлением Правительства Республики Казахстан от 1 ноября 1996 года № 1342 и определено единственным государственным научным метрологическим центром в Республике Казахстан [1].

Основной задачей является защита интересов граждан и экономики Республики Казахстан от последствий недостоверных результатов измерений, обеспечение безопасности и качества отечественной и импортируемой продукции, процессов (работ) и услуг.

Предметом и целью деятельности РГП «КазИнМетр» является [1]:

- проведение испытаний изготавливаемых в Республике Казахстан и импортируемых средств измерений на соответствие установленным требованиям;

- усовершенствование технической (эталонной) базы; 
- гармонизация нормативных документов по метрологии для обеспечения единства измерений с международными требованиями;

- подготовка и повышение квалификации кадров в области метрологии;

- информационное обеспечение физических и юридических лиц по вопросам обеспечения единства измерений.

Роль обеспечения единства измерений в области различных форм собственности не менее важно. Закон РК «Об обеспечении единства измерений» позволяет сохранить принцип государственного характера метрологического обеспечения. Это выражается прежде всего в том, что теперь в Казахстане действует не только государственные метрологические организации, но и службы юридических лиц, а также коммерческие метрологические службы. В соответствии с Законом поверка средств измерений осуществляется государственной метрологической службой, а также метрологическими службами юридических лиц, аккредитованными уполномоченным государственным органом по стандартизации, метрологии и сертификации [7].

Республика Казахстан стала членом следующих международных и региональных организаций по метрологии [7]:

- Международной организации законодательной метрологии (МОЗМ) с октября 1994г;

- Евро-Азиатского Сотрудничества Государственных Метрологических Учреждений (КООМЕТ) с ноября 1998г.;

- Межгосударственного совета по стандартизации, метрологии и сертификации стран СНГ (МГС) с марта 1992г.

В гармонизации действующей системы измерений, eе законодательной и нормативной основ, приведения к эквивалентности государственных эталонов республики принято решение о присоединении республики к Метрической конвенции и активации деятельности в рамках международных организаций по метрологии. Предстоящее вступление Казахстана во Всемирную торговую организацию, расширение международной торговли и сотрудничества обязывают метрологов республики осуществлять дальнейшие шаги по совершенствованию национальной системы измерений как механизма обеспечения единства измерений в стране, гарантии возможности обеспечения качества и безопасности импортируемой и экспортируемой продукции.

Проведение испытаний изготавливаемых в Республике Казахстан и импортируемого медицинского оборудования на соответствие установленным требованиям из стран Китай, Япония, Финляндия, Россия, Украина, Турция, Германия, Италия, Киргизия, Бразилия, Аргентина, США, Чехия и др. - является одним из приоритетов развития в рамках программы «Казахстан 2030» [2-6]. 


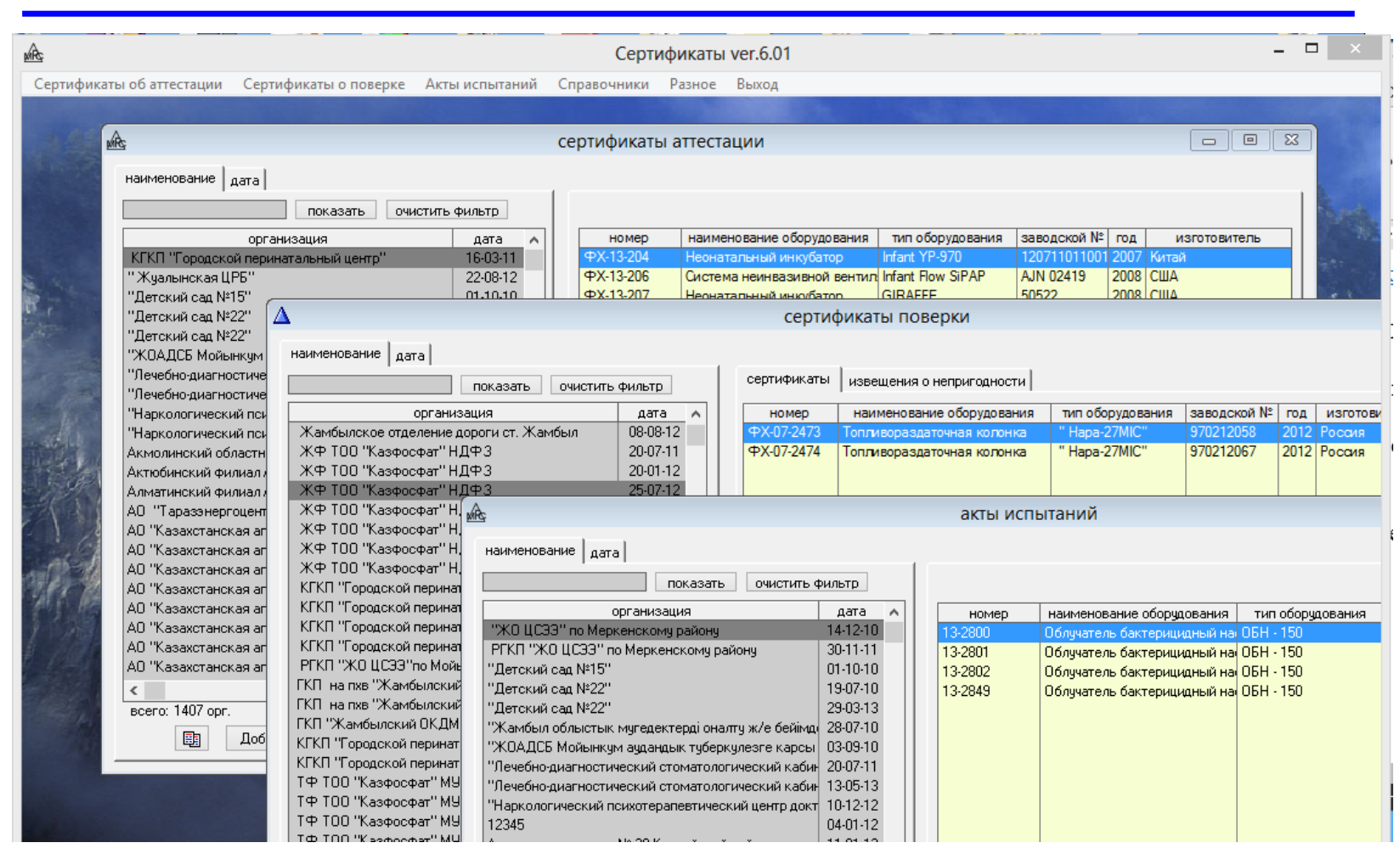

\section{Рисунок 1 - База сертификатов организаций.}

Сертификацию в Казахстане осуществляют более 50 частных ТОО. Рассмотрим статистику на примере одной из таких фирм за 2010 год (Рис.1). Статистические данные о количестве выданных сертификатов приведены в табл.1.

Таблица 1

\section{Статистика сертификации медицинских организаций.}

\begin{tabular}{|c|c|c|c|c|}
\hline Название фирмы & $\begin{array}{c}\text { Кол-во } \\
\text { сертификатов } \\
\text { об аттестации }\end{array}$ & $\begin{array}{c}\text { Кол-во } \\
\text { сертификатов о } \\
\text { поверке } \\
\end{array}$ & $\begin{array}{c}\text { Кол-во } \\
\text { актов } \\
\text { испытаний }\end{array}$ & Всего \\
\hline Областной офтальмологический центр & 40 & 16 & 8 & 64 \\
\hline Лечебный центр "Эскулап" & 1 & 9 & 9 & 19 \\
\hline Городская детская больница №1 & 27 & 56 & 4 & 87 \\
\hline Жамбылский филиал ГУ ЦСМ МЗ РК & 6 & 48 & & 54 \\
\hline $\begin{array}{l}\text { ГУ } \\
\text { психоневрологический диспансер" }\end{array}$ & 9 & 21 & 96 & 126 \\
\hline $\begin{array}{l}\text { Стоматологический кабинет и.п.Махмудова } \\
\text { Д.А. }\end{array}$ & 2 & & 6 & 8 \\
\hline ВА "Беткайнар" & 4 & 6 & 10 & 20 \\
\hline ВА "Жамбыл" & 4 & 6 & 8 & 18 \\
\hline ВА "Кайнар" & 3 & 3 & 8 & 14 \\
\hline ВА "Касык" & 2 & & & 2 \\
\hline BA "Степное" & 3 & 5 & 12 & 20 \\
\hline ВА "Ногайбай" & 3 & 1 & 6 & 10 \\
\hline Кордайская ЦРБ & 41 & 52 & 54 & 147 \\
\hline Кордайская ЦРП & 15 & 15 & 68 & 98 \\
\hline МП "Шарбакты" & 1 & & & 1 \\
\hline $\begin{array}{l}\text { Частный гинекологический кабинет Ким } \\
\text { В.Ф. }\end{array}$ & 1 & & 1 & 2 \\
\hline АО "Санаторий Мерке" & 3 & 30 & 4 & 37 \\
\hline $\begin{array}{l}\text { Дом интернат для престарелых и инвалидов } \\
\text { №1 }\end{array}$ & 2 & 4 & 10 & 16 \\
\hline
\end{tabular}




\begin{tabular}{|c|c|c|c|c|}
\hline КГКП "Городская поликлиника № 7" & 11 & 21 & 31 & 63 \\
\hline Учреждение "ЖД 158/1" & 6 & 3 & 10 & 19 \\
\hline Центр ПМСП № 5 & 5 & 4 & & 9 \\
\hline $\begin{array}{lc}\text { Стоматологический } & \text { кабинет } \\
\text { и.п.Дуйсенбаева А.Р. } & \\
\end{array}$ & 2 & & 3 & 5 \\
\hline $\begin{array}{l}\text { Стоматологический } \quad \text { кабинет Байзаковой } \\
\text { C.M. с. Кулан Б. ул.Жибек Жолы }\end{array}$ & 1 & & 2 & 3 \\
\hline Городская поликлиника №4 & 14 & 21 & 39 & 74 \\
\hline $\begin{array}{l}\text { Стоматологический кабинет Шкуратовой } \\
\text { Г.В. }\end{array}$ & 1 & & 5 & 6 \\
\hline $\begin{array}{l}\text { Стоматологический кабинет И.П. Саркеева } \\
\text { Ж.К. }\end{array}$ & 2 & & 6 & 8 \\
\hline ТОО Санэпидветлаборатория "Толебай" & 3 & 6 & & 9 \\
\hline Центр ПМСП № 3 & 2 & 3 & & 5 \\
\hline BA "Каракемер" & 3 & & & 3 \\
\hline BA "Орнек" & 7 & 9 & 8 & 24 \\
\hline $\begin{array}{l}\text { Противотуберкулезная больница Таласского } \\
\text { района }\end{array}$ & 3 & 2 & & 5 \\
\hline ВА "Берлису Енбен" & 1 & & & 1 \\
\hline ВА"Пионер" & 1 & & & 1 \\
\hline ВА"Шайдана" & 1 & & & 1 \\
\hline МП"Енбек" & 1 & & & 1 \\
\hline МП"Октябрь Женис" & 1 & & & 1 \\
\hline ВА"Тактюбе" & 1 & & & 1 \\
\hline $\begin{array}{l}\text { КГКП "Больница скорой } \\
\text { помощи" }\end{array}$ & 40 & 52 & 34 & 126 \\
\hline КГКП "Городская поликлиника № 1" & 14 & 22 & 40 & 76 \\
\hline Жамбылская ЦРБ & 15 & 31 & 48 & 94 \\
\hline $\begin{array}{l}\text { КГКП "Жамбылская областная детская } \\
\text { стоматологическая поликлиника" }\end{array}$ & 4 & 6 & & 10 \\
\hline $\begin{array}{l}\text { Областной консультативно-диагностический } \\
\text { медицинский центр }\end{array}$ & 37 & 46 & 21 & 104 \\
\hline $\begin{array}{lll}\text { КГКП "Городская } & \text { поликлиника } & \text { №6 } \\
\text { УЗАЖО" } & & \\
\end{array}$ & 2 & 2 & 15 & 19 \\
\hline $\begin{array}{l}\text { Стоматологический кабинет док.Оспанова } \\
\text { С.С. }\end{array}$ & 4 & 2 & 7 & 13 \\
\hline $\begin{array}{lc}\text { Стоматологический } & \text { кабинет } \\
\text { и.п.Жигитековой 3.A } & \\
\end{array}$ & 1 & & 2 & 3 \\
\hline ТОО МЦ "Добрый самарянин" & 2 & 2 & 6 & 10 \\
\hline АО "Таразэнергоцентр" Здравпункт & 1 & 13 & 2 & 16 \\
\hline ГДБ & 1 & & 3 & 4 \\
\hline ОДБ & 1 & & 3 & 4 \\
\hline $\begin{array}{l}\text { Противотуберкулезный } \\
\text { Жамбылского района }\end{array}$ & 2 & 5 & 12 & 19 \\
\hline Солнечный & 1 & & 3 & 4 \\
\hline СШ №39 & 1 & & 1 & 2 \\
\hline СШ №40 & & & 1 & 1 \\
\hline СШ №44 & 1 & & 1 & 2 \\
\hline СШ №54 & 1 & & 1 & 2 \\
\hline СШ №6 & 1 & & 1 & 2 \\
\hline $\begin{array}{l}\text { TОО "Куляйхан", } \\
\text { район,с.Жаксылык:Т.РыскуловсЖамбылова,22 }\end{array}$ & 1 & & 4 & 5 \\
\hline $\begin{array}{l}\text { TOО "Шагала", Адрес: c. Кулан, } \\
\text { Рыскуловского района }\end{array}$ & 1 & & 6 & 7 \\
\hline ВА "Айша Бибі" & 1 & 4 & 7 & 12 \\
\hline ВА "Акбулум" & 2 & 3 & 5 & 10 \\
\hline BA "Бесагаш" & 1 & & 6 & 7 \\
\hline ВА "Гродиково" & 4 & 9 & 12 & 25 \\
\hline ВА "Жалпак Тобе" & 2 & 4 & 8 & 14 \\
\hline
\end{tabular}




\begin{tabular}{|c|c|c|c|c|}
\hline ВА "Жасуркен" & 3 & 5 & 10 & 18 \\
\hline ВА "Кумшагал" & 2 & 3 & 7 & 12 \\
\hline ВА "Кызыл-Абад" & 1 & & 3 & 4 \\
\hline ВА "Пригородное" & 3 & 1 & 12 & 16 \\
\hline ВА "Турксиб" & 2 & 3 & 9 & 14 \\
\hline ВА "Шолдала" & 1 & & 6 & 7 \\
\hline КГКП "Центр ПМСП Масанчи" & 3 & 3 & 13 & 19 \\
\hline КГКП "Центр ПМСП Отар" & 2 & 4 & 14 & 20 \\
\hline КГКП Карасайская сельская больница & 2 & 1 & 5 & 8 \\
\hline КГКП Отарская сельская больница & 2 & 4 & 14 & 20 \\
\hline КГКП Сельская больница Аухатты & 4 & 4 & 6 & 14 \\
\hline $\begin{array}{ll}\text { ГУ } & \text { "Противотуберкулезный } \\
\text { Т.Рыскуловского района" } & \\
\end{array}$ & 16 & 10 & 72 & 98 \\
\hline ТОО "Санаторий Ак Ниет" & 2 & 14 & 10 & 26 \\
\hline $\begin{array}{l}\text { ГКП на праве хозяйственного ведения "ЦРБ } \\
\text { Мойынкумского района УЗАЖО" }\end{array}$ & 17 & 23 & 46 & 86 \\
\hline $\begin{array}{l}\text { КГКП "Центральная районная поликлиника } \\
\text { Жамбылского района УЗАЖО" }\end{array}$ & 15 & & 38 & 53 \\
\hline МП "Жамбыл" & 1 & & 1 & 2 \\
\hline ГУ Дом детства "Улан" & 1 & & 11 & 12 \\
\hline АО "Меркенский сырзавод" & 2 & & & 2 \\
\hline $\begin{array}{l}\text { ГКП на праве хозяйственного ведения "ЦРБ } \\
\text { Мойынкумского района УЗАЖО" }\end{array}$ & 21 & 23 & 46 & 90 \\
\hline КФ АО "КазАгрЭкс" & 3 & 18 & & 21 \\
\hline КФ АО "КазАгрЭкс" Жалагаш & 1 & 4 & & 5 \\
\hline КФ АО "КазАгрЭкс" Кармакшы & 1 & 1 & & 2 \\
\hline КФ АО "КазАгрЭкс" Теренозек & 1 & 5 & & 6 \\
\hline КФ АО "КазАгрЭкс" Шиели & 1 & 1 & & 2 \\
\hline Семенная инспекция пункт, пос. Шиели & 1 & 11 & & 12 \\
\hline Семенной экспертный пункт, пос. Жалагаш & 2 & 1 & & 3 \\
\hline $\begin{array}{llll}\text { Семенной } & \text { экспертный } & \text { пункт, } & \text { пос. } \\
\text { Жанакорган } & & \end{array}$ & 2 & 1 & & 3 \\
\hline Семенной экспертный пункт, пос. Казалы & 2 & 1 & & 3 \\
\hline $\begin{array}{lccc}\text { Семенной } & \text { экспертный } & \text { пункт, } & \text { пос. } \\
\text { Кармакшы } & & & \\
\end{array}$ & 1 & 1 & & 2 \\
\hline Семенной экспертный пункт, пос. Теренозек & 2 & 1 & & 3 \\
\hline $\begin{array}{l}\text { Дом интернат для престарелых и инвалидов } \\
\text { №3 }\end{array}$ & 1 & 6 & 7 & 14 \\
\hline $\begin{array}{l}\text { ГУ "Жамбылская противочумная станция" } \\
\text { КГСЭН МЗ РК }\end{array}$ & 29 & 4 & 13 & 46 \\
\hline М.Ц. "Доктор Ю" & 3 & 2 & 6 & 11 \\
\hline РГКП "ЖО ЦСЭЭ" КГСЭН МЗ РК & 5 & & & 5 \\
\hline $\begin{array}{l}\text { РГКП "ЖОЦСЭЭ" КГСЭН } \\
\text { Жуалынскому району }\end{array}$ & 1 & 17 & & 18 \\
\hline $\begin{array}{l}\text { РГКП "ЖОЦСЭЭ" КГСЭН } \\
\text { Сарысускому району }\end{array}$ & 3 & 19 & & 22 \\
\hline $\begin{array}{l}\text { РГКП "ЖОЦСЭЭ" КГСЭН МЗ РК по Т. } \\
\text { Рыскуловскому району }\end{array}$ & 3 & 23 & & 26 \\
\hline $\begin{array}{lrr}\text { Стоматологический } & \text { кабинет } & \text { и.п. } \\
\text { Мухаметкеримовой P.М. с.Кордай } & \\
\end{array}$ & 1 & & & 1 \\
\hline $\begin{array}{l}\text { Филиал РГКП "ЖО ЦСС" по Жуалынскому } \\
\text { району }\end{array}$ & 7 & & & 7 \\
\hline $\begin{array}{l}\text { Филиал РГКП "ЖО ЦСС" по Сарысускому } \\
\text { району }\end{array}$ & 4 & & & 4 \\
\hline $\begin{array}{lcccc}\begin{array}{l}\text { Филиал РГКП "ЖО } \\
\text { Рыскуловскому району }\end{array} & \text { ЦСС" } & \text { по } & \text { Т- } \\
\end{array}$ & 7 & & & 7 \\
\hline ВА "Бурыл" Байзакского района & 4 & & 16 & 20 \\
\hline ВА "Коктал" Байзакского района & 2 & 4 & 5 & 11 \\
\hline Ц Центр ПМСП "Бурыл" Байзакского района & 4 & 3 & & 7 \\
\hline
\end{tabular}




\begin{tabular}{|c|c|c|c|c|}
\hline "Детский сад №15" & 2 & & 7 & 9 \\
\hline ВА "Жетибай" & 4 & & 8 & 12 \\
\hline ВА "Мырзатай" & 5 & 1 & 9 & 15 \\
\hline МП "Аккия" & 1 & & 5 & 6 \\
\hline МП "Дикан" & 1 & & 4 & 5 \\
\hline МП "Сенкибай" & 1 & & 4 & 5 \\
\hline ВА "Костобе 1" & & & 5 & 5 \\
\hline ВА "Костобе 2" & 4 & 4 & 11 & 19 \\
\hline МП "Станция Талас" & 2 & 1 & 2 & 5 \\
\hline ВА "Абай" & 1 & 1 & 7 & 9 \\
\hline ВА "Кенес" & 4 & 3 & 8 & 15 \\
\hline ВА "Тегистик" & 1 & & 3 & 4 \\
\hline ВА "Ынтымак" & 1 & & 6 & 7 \\
\hline МП "Жанасас" & 1 & & 1 & 2 \\
\hline ВА "Костобе 1" & 2 & & 5 & 7 \\
\hline Госпиталь с поликлиникой ДВД & 5 & 19 & 14 & 38 \\
\hline СЭС ДВД & 3 & 2 & 1 & 6 \\
\hline КГКП Городская больница № 2 & 13 & 14 & 72 & 99 \\
\hline ВА "Кылышбай" & & & 1 & 1 \\
\hline $\begin{array}{l}\text { ГКП на праве хлзяйственного ведения "ЦРП } \\
\text { Мойынкумского района" УЗАЖО }\end{array}$ & & 11 & 18 & 29 \\
\hline Клиника доктора Кученева & 19 & 16 & 41 & 76 \\
\hline Областной центр крови & 19 & 2 & 26 & 47 \\
\hline Городская детская больница №1 & 22 & 56 & 29 & 107 \\
\hline $\begin{array}{l}\text { ФАО "Железнодорожные госпитали } \\
\text { катастроф" Шуйская ж/д больница }\end{array}$ & 5 & & & 5 \\
\hline ЖОФ РГКП ЮВРЦСЭЭ на ж.д. транспорте & 6 & 14 & & 20 \\
\hline ТОО "Турур и К" г.Жанатас & 1 & & 9 & 10 \\
\hline Медицинское учреждение "Vita Lu x" & 1 & & & 1 \\
\hline $\begin{array}{ll}\text { Противотуберкулезный } & \text { диспансер } \\
\text { Сарысуского района } & \end{array}$ & 15 & 17 & & 32 \\
\hline ЖОРЦ "Материнство и Детство" & 7 & 17 & 27 & 51 \\
\hline $\begin{array}{l}\text { Стоматологический кабинет "Мила Дент" с. } \\
\text { Мерке }\end{array}$ & 1 & & & 1 \\
\hline \begin{tabular}{lcr} 
ФАО"Железнодорожные & \multicolumn{2}{c}{ госпитали } \\
медицины & катастроф"'"Шуская & ж/д \\
больница" & & \\
\end{tabular} & 6 & 9 & & 15 \\
\hline МУ "Денсаулык" & 4 & 2 & 7 & 13 \\
\hline Городская поликлиника № 3 & 13 & & 72 & 85 \\
\hline $\begin{array}{l}\text { Жамбылс. } \text { областной } \text { центр } \\
\text { формирования здорового образа жизни }\end{array}$ & 2 & 3 & 7 & 12 \\
\hline $\begin{array}{l}\text { ГУ "Шу-Таласский } \\
\text { КЭРиК Мепартаментэкологии }\end{array}$ & 3 & 16 & & 19 \\
\hline Областной наркологический диспансер & 2 & 4 & 5 & 11 \\
\hline $\begin{array}{l}\text { Стоматологичсекий кабинет и.п.Машанло } \\
\text { П.Ц. Кордайский район, с.Сортобе }\end{array}$ & 3 & 1 & 6 & 10 \\
\hline $\begin{array}{l}\text { Филиал РГКП "ЖО ЦСЭЭ" по Меркенскому } \\
\text { району }\end{array}$ & 10 & 20 & 8 & 38 \\
\hline Жуалынская ЦРБ & 1 & 35 & & 36 \\
\hline $\begin{array}{llll}\begin{array}{l}\text { Филиал РГКП "ЖО } \\
\text { Жамбылскому району }\end{array} & \text { ЦСЭЭ" } & \text { по } \\
\end{array}$ & 10 & & & 10 \\
\hline $\begin{array}{l}\text { Филиал РГКП "ЖО ЦСЭЭ" по Шускому } \\
\text { району }\end{array}$ & 10 & & & 10 \\
\hline $\begin{array}{l}\text { Центральная районная } \\
\text { Байзакского района }\end{array}$ & 6 & 22 & 47 & 75 \\
\hline ЖФ ТОО "КЕСО ОТАН" & 1 & & & 1 \\
\hline $\begin{array}{l}\text { Филиал РГКП "ЖО ЦСЭЭ" по Кордайскому } \\
\text { району }\end{array}$ & 10 & 20 & 1 & 31 \\
\hline психоневрологический & 4 & 13 & 71 & 88 \\
\hline
\end{tabular}




\begin{tabular}{|c|c|c|c|c|}
\hline диспансер & & & & \\
\hline $\begin{array}{ll}\text { Жамбылский } & \text { областной } \\
\text { офтальмологический центр } & \end{array}$ & 8 & 11 & 8 & 27 \\
\hline ВА "Акжар" & 1 & 2 & 3 & 6 \\
\hline BA "Дихан" & 3 & 2 & 6 & 11 \\
\hline ВА "Сухамбай" & 4 & 4 & & 8 \\
\hline Городская поликлиника № 2 & 1 & 6 & 1 & 8 \\
\hline СВА "Туймекент" & 4 & 8 & 16 & 28 \\
\hline $\begin{array}{l}\text { ТОО "Арай Дент"; Адрес: г. Тараз, ул. Толе- } \\
\text { би, } 16\end{array}$ & 2 & & 6 & 8 \\
\hline $\begin{array}{lcc}\text { Филиал } & \text { РГКП"ЖО } & \text { ЦСЭЭ"по } \\
\text { Мойынкумскому району } & \end{array}$ & 12 & 23 & & 35 \\
\hline $\begin{array}{l}\text { Филиал РГКП "ЖО ЦСЭЭ" по Байзакскому } \\
\text { району }\end{array}$ & 8 & 24 & & 32 \\
\hline РГКП "ЖО ЦСЭЭ" по Таласскому району & 10 & 19 & & 29 \\
\hline $\begin{array}{l}\text { Филиал РГКП "ЖО ЦСЭЭ" по Таласскому } \\
\text { району }\end{array}$ & 10 & & & 10 \\
\hline ЖОФ РГКП ЮВРЦСЭЭ на ж/д транспорта & 9 & 4 & & 13 \\
\hline МЦ "Жаншуак" & 5 & 1 & 6 & 12 \\
\hline Ч.П. Комарова "Семья" & 1 & 2 & 5 & 8 \\
\hline ГУ "Учреждение ЖД 158/2" & 4 & 1 & & 5 \\
\hline ЖФ АО "КАЗАГРЭКС" & 6 & 21 & & 27 \\
\hline Филиал ГП № 2 ВА № 4 & 3 & & 20 & 23 \\
\hline ВА "Байзак" & 3 & 4 & 11 & 18 \\
\hline BA "Жанатурмыс" & 4 & 4 & 10 & 18 \\
\hline ВА Жанатурмыс района им. Т. Рыскулова & 2 & 2 & 6 & 10 \\
\hline ВА Каракыстак района им. Т. Рыскулова & 2 & 2 & 8 & 12 \\
\hline ВА Кокдонен района им. Т. Рыскулова & 4 & 3 & 7 & 14 \\
\hline ВА Кумарык района им. Т. Рыскулова & 3 & 3 & 6 & 12 \\
\hline ВА"Улгілі" Байзакского района & 1 & & 2 & 3 \\
\hline $\begin{array}{l}\text { КГКП "Жамбылский } \quad \text { областной } \text { центр } \\
\text { крови" }\end{array}$ & 3 & 13 & 26 & 42 \\
\hline МП "Ботамойнак" & 1 & & 1 & 2 \\
\hline МП "Жанатурмыс" & 1 & & 3 & 4 \\
\hline МП Алгабас района им. Т. Рыскулова & 1 & & 2 & 3 \\
\hline ФП "Акшолак" & 1 & & 3 & 4 \\
\hline ВА Абай района им. Т. Рыскулова & 1 & 1 & 4 & 6 \\
\hline ВА Когершин района им. Т. Рыскулова & 2 & 3 & 6 & 11 \\
\hline $\begin{array}{l}\text { ФАП Военный городок района им. Т. } \\
\text { Рыскулова }\end{array}$ & 1 & & 2 & 3 \\
\hline ЦРП района им. Т. Рыскулова & 16 & & 43 & 59 \\
\hline $\begin{array}{l}\text { КГКП "ОРЦ для детей с неврологической } \\
\text { патологией" }\end{array}$ & 4 & 2 & 20 & 26 \\
\hline ТОО "Оптимед" & 2 & & & 2 \\
\hline
\end{tabular}

Результаты анализа статистики сертификации медицинского оборудования (Табл.1) для различных организаций за 2010 г. приведены на рис.2. 


\section{0 г.}

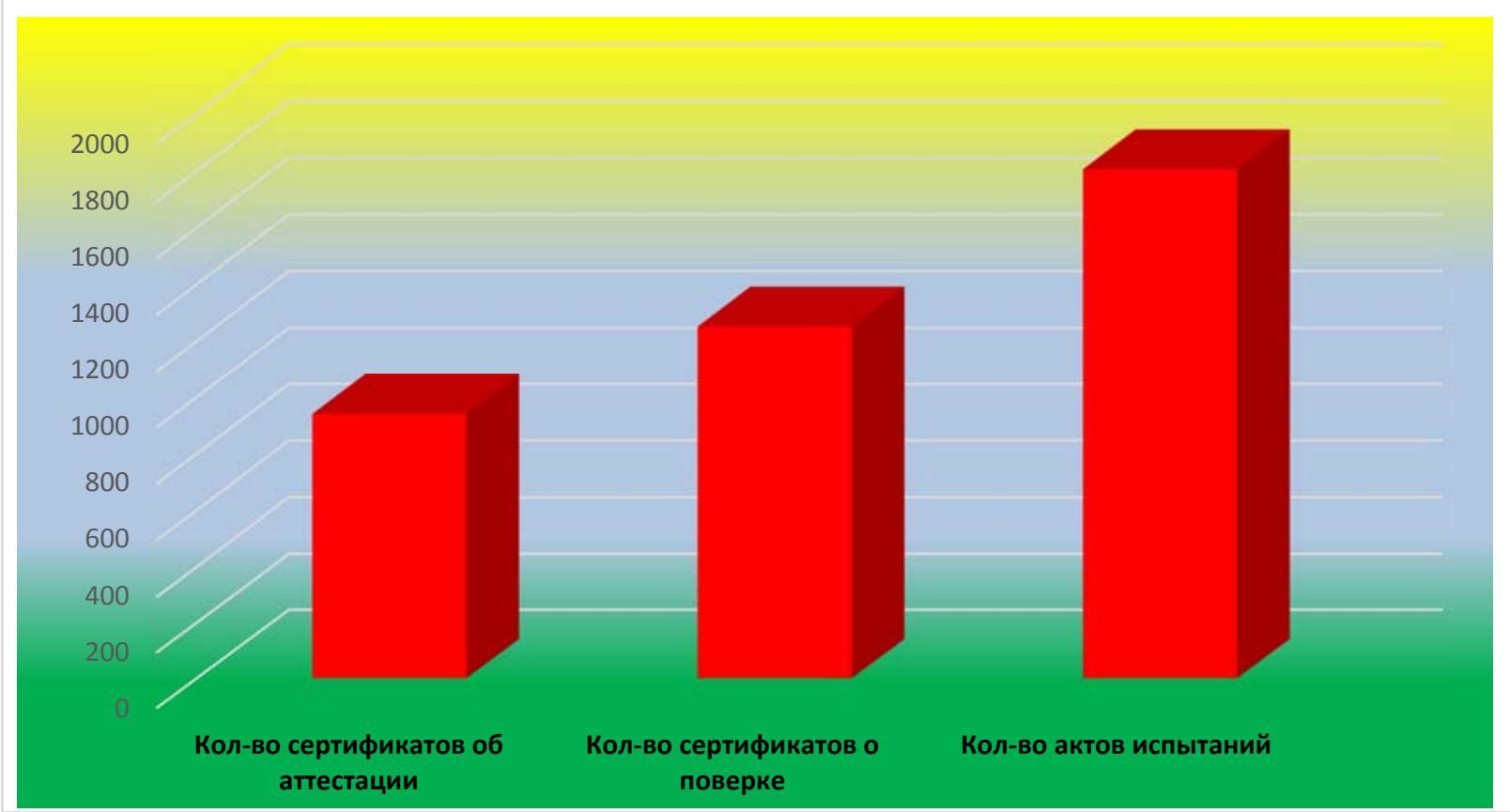

Рисунок 2 - Анализ статистики сертификации медицинского оборудования для различных организаций.

\section{References:}

1. РГП "Казахстанский институт метрологии" [Электронный ресурс] http://www.analitika.kz/vlast-ispolnitelnaya-ministerstva-rk/rgp-kazahstanskij-institutmetrologii (Дата доступа 17.07.2014).

2. Закон Республики Казахстан «Об обеспечении единства измерений» от 07.06.2000 г.

3. Мырзабай М.М. и др. Основы стандартизации, метрологии, сертификации и менеджмента качества А.: издат. ЧП «ЮАТ» 2003 г.

4. Кобзарь Н.Я. Законодательство в области поверки средств измерений Метрология №2, 2001 c. 52-53

5. Сертификаты ver.6.01. - 2014.

6. Крылова Г.Д. Основы стандартизации, сертификации и метрологии: Учебник для ВУЗов. - М «ЮНИТИ», 1998 г.

7. Испытания и аккредитация средств измерений в РГП "КазИнМетр" [Электронный pecypc] http://www.bibliofond.ru/view.aspx?id=517375 (Дата доступа 17.07.2014). 